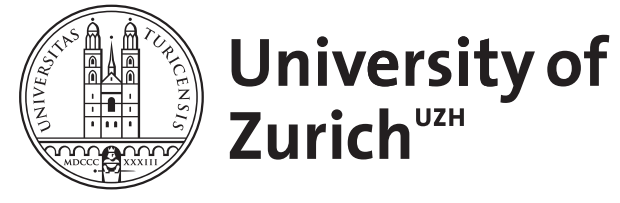

\title{
Fas ligand expression in the organ of Corti
}

\author{
Bodmer, D ; Brors, D ; Bodmer, M ; Pak, K ; Ryan, A F
}

\begin{abstract}
We have previously demonstrated by FACS analysis and histochemistry that Fas ligand (FasL) increases on cochlear cell surfaces after immune response or stimulation with gamma-interferon (IFNgamma). To determine whether the appearance of FasL on cochlear cell membranes is related to gene expression or to posttranslational events, cochlear cells were treated with IFN-gamma. They were evaluated for FasL gene expression by real-time PCR and for FasL protein localization by confocal microscopy of permeabilized and immunolabeled cells. Real-time PCR analysis of cDNAs generated from unstimulated or IFN-gamma-stimulated organ of Corti demonstrated no change in the transcription of the gene encoding FasL. In contrast, confocal microscopy revealed dramatic changes in the cellular distribution of FasL, consistent with movement from the endoplasmic reticulum to the cytoplasm and cell membrane. The results suggest that recruitment of preformed FasL from intracellular compartments, rather than its biosynthesis, is responsible for the increase in FasL on the cell surface following IFN-gamma stimulation. This is similar to the response of cytotoxic $\mathrm{T}$ lymphocytes in which gene expression is not involved in FasL surface appearance. Presumably, the use of preformed FasL increases the rapidity of this response. FasL localization to the membrane may be involved in protecting the inner ear from autoimmunity or inflammation. Alternatively it may be related to cochlear cell death in response to inflammatory stress.
\end{abstract}

DOI: https://doi.org/10.1159/000071996

Posted at the Zurich Open Repository and Archive, University of Zurich

ZORA URL: https://doi.org/10.5167/uzh-8426

Journal Article

Published Version

Originally published at:

Bodmer, D; Brors, D; Bodmer, M; Pak, K; Ryan, A F (2003). Fas ligand expression in the organ of Corti. Audiology and Neurotology, 8(5):243-249.

DOI: https://doi.org/10.1159/000071996 


\title{
Fas Ligand Expression in the Organ of Corti
}

\author{
Daniel Bodmer ${ }^{a}, b \quad$ Dominik Brors ${ }^{a}$ Morana Bodmer ${ }^{a} \quad K_{w a n g}$ Pak $^{a}$ \\ Allen F. Ryan ${ }^{a}$ \\ a Department of Surgery, Division of Otolaryngology, UCSD School of Medicine, and VA Medical Center, \\ La Jolla, Calif., USA; 'b Department of Otolaryngology, Head and Neck Surgery, University Hospital Zurich, \\ Zurich, Switzerland
}

\section{Key Words}

Fas ligand - Gene expression · Hair cells • Organ of Corti · Rat $\cdot$ Real-time polymerase chain reaction

\begin{abstract}
We have previously demonstrated by FACS analysis and histochemistry that Fas ligand (FasL) increases on cochlear cell surfaces after immune response or stimulation with $\gamma$-interferon (IFN- $\gamma$ ). To determine whether the appearance of FasL on cochlear cell membranes is related to gene expression or to posttranslational events, cochlear cells were treated with IFN- $\gamma$. They were evaluated for FasL gene expression by real-time PCR and for FasL protein localization by confocal microscopy of permeabilized and immunolabeled cells. Real-time PCR analysis of cDNAs generated from unstimulated or IFN- $\gamma$-stimulated organ of Corti demonstrated no change in the transcription of the gene encoding FasL. In contrast, confocal microscopy revealed dramatic changes in the cellular distribution of FasL, consistent with movement from the endoplasmic reticulum to the cytoplasm and cell membrane. The results suggest that recruitment of preformed FasL from intracellular compartments, rather than its biosynthesis, is responsible for the increase in
\end{abstract}

The first two authors contributed equally to this study.
FasL on the cell surface following IFN- $\gamma$ stimulation. This is similar to the response of cytotoxic $T$ lymphocytes in which gene expression is not involved in FasL surface appearance. Presumably, the use of preformed FasL increases the rapidity of this response. FasL localization to the membrane may be involved in protecting the inner ear from autoimmunity or inflammation. Alternatively it may be related to cochlear cell death in response to inflammatory stress.

Copyright (C) 2003 S. Karger AG, Basel

\section{Introduction}

Apoptosis, or programmed cell death, selectively targets certain cells to undergo cell death following distinct biological signals. It plays an important role in development and tissue homeostasis [Zimmermann et al., 2001]. In general, there are two intracellular pathways leading to apoptosis, an intrinsic and an extrinsic pathway. In the intrinsic pathway, mitochondria release apoptogenic factors into the cytoplasm, which then activate the downstream execution phase of apoptosis [Kluck et al., 1997]. In the extrinsic pathway, death receptors such as Fas and TNFR1 initiate apoptosis upon ligand binding. Apoptotic cell death mediated by Fas is widespread in the immune system, where it serves in the deletion of activated peripheral lymphocytes [Nagata and Golstein, 1995].

Allen F. Ryan, $\mathrm{PhD}$

UCSD School of Medicine

9500 Gilman Drive No. 0666

La Jolla, CA 92093 (USA)

Tel. +1 858534 4594, Fax +1 858534 5319, E-Mail afryan@ucsd.edu
Fax + 41613061234

E-Mail karger@karger.ch

www.karger.com
Accessible online at: www.karger.com/aud 
The Fas and Fas ligand (FasL) system was initially identified because of its involvement in the regulation of apoptosis in the immune system [Nagata and Golstein, 1995]. FasL is a trimeric type II membrane protein of approximately $37 \mathrm{kD}$ [Suda et al., 1993]. When FasL binds to its receptor Fas, caspases are activated and the cell typically dies by apoptosis [Nagata and Golstein, 1995]. The Fas receptor is expressed on many cell types, including most inflammatory cells. However, as might be expected for a death ligand, the display of FasL on the cell surface is tightly regulated. This molecule is expressed on immune cells such as activated T cells [Suda et al., 1995], natural killer cells [Oshimi et al., 1996] as well as on nonimmune cells such as cells in the corneal epithelium and the retina in the eye [Griffith et al., 1996] and Sertoli cells in the testis [Bellgrau et al., 1995]. FasL can also be expressed on the cell surface of other cell types in response to tissue damage and inflammation.

Recently, we have demonstrated by FACS analysis and immunohistochemistry that FasL on the surface of cochlear cells increases after stimulation with $\gamma$-interferon (IFN- $\gamma$ ) or after the induction of a sterile labyrinthitis [Bodmer et al., 2002]. It may be involved in the defense of inner ear tissue from inflammation and immunity, as has been suggested for the anterior chamber of the eye [Griffith et al., 1996]. In the present study, we explored the mechanisms by which cells of the organ of Corti (OC) increase the level of FasL after stimulation with IFN- $\gamma$. We employed real-time PCR, a highly sensitive method, to quantify cDNA produced by reverse transcription of mRNA from OC stimulated with IFN- $\gamma$. We also used confocal microscopy to localize FasL in isolated, permeabilized cochlear cells.

\section{Material and Methods}

\section{Animals and Dissection}

All animal procedures have been carried out according to NIH guidelines and followed an approved animal research protocol (VA Medical Center, La Jolla, Calif., USA). The entire OC was dissected from postnatal day 5 Sprague-Dawley rats according to the description of others [Van de Water and Ruben, 1971, 1974; Sobkowicz et al., 1993].

\section{Cell Culture}

The cultures were maintained in Dulbecco's modified Eagle medium with $10 \%$ fetal bovine serum, $25 \mathrm{~m} M$ Hepes buffer and $30 \mathrm{U} / \mathrm{ml}$ penicillin for $24 \mathrm{~h}$. Two OC were pooled per well, and in the experimental group, the OC were stimulated with $100 \mathrm{IU} / \mathrm{ml}$ of recombinant rat IFN- $\gamma$ (R\&D Systems Inc., USA) for $12 \mathrm{~h}$, which was repeated for an additional hour just prior to mRNA extraction. Control explants remained in culture medium alone.

\section{RNA Isolation}

The mRNA was isolated using oligo-dT magnetic microbeads (Dyna-beads; Dynal) as previously described [Housley et al., 1995]. The mRNA was released from the beads by incubation in $10 \mathrm{mM}$ Tris- $\mathrm{HCl}$ buffer (pH 7.5) at $80^{\circ} \mathrm{C}$ for $5 \mathrm{~min}$. First-strand cDNA synthesis was performed using the superscript preamp System (GibcoBRL) and primed with oligo-dT.

\section{PCR Standardization}

PCR to produce a FasL DNA standard was performed using primers specific for FasL: FasL sense primer, 5'-GACCACAAGGTCCAACAGG-3'; FasL antisense primer, 5'-GACATCATTGCACTGGAGG-3'. PCR was performed at $94^{\circ} \mathrm{C}$ for $3 \mathrm{~min}$ followed by 45 cycles of amplification. Each cycle consisted of 1 min denaturation at $94^{\circ} \mathrm{C}, 1 \mathrm{~min}$ of annealing at $55^{\circ} \mathrm{C}$ and $1 \mathrm{~min}$ for enzymatic primer extension at $72^{\circ} \mathrm{C}$. After the final cycle, the temperature was held at $72^{\circ} \mathrm{C}$ for $7 \mathrm{~min}$ to allow re-annealing of the amplified products. The PCR product was size-fractionated through a $1.5 \%$ agarose gel, and the bands were visualized with the use of ethidium bromide. The DNA was isolated (Gel Extraction Kit, Qiagen) and cloned into the pCR-II Topo vector (Topo-TA-Kit; Invitrogen). Subsequent sequencing revealed the expected sequence of the FasL fragment (BLAST). PCR to produce a $\beta$-actin standard (primer set provided by Ambion, USA) had the following conditions: $94^{\circ} \mathrm{C}$ for $3 \mathrm{~min}$ followed by 35 cycles of amplification. Each cycle consisted of $1 \mathrm{~min}$ of denaturation at $94^{\circ} \mathrm{C}, 1 \mathrm{~min}$ of annealing at $60^{\circ} \mathrm{C}$ and $1 \mathrm{~min}$ for enzymatic primer extension at $72^{\circ} \mathrm{C}$. After the final cycle, the temperature was held at $72^{\circ} \mathrm{C}$ for $7 \mathrm{~min}$ to allow re-annealing of the amplified products. The $\beta$-actin product was cloned and sequenced as above.

\section{Real-Time PCR}

The samples were then analyzed by real-time PCR on the Smart Cycler TD (Cepheid, Calif., USA) using the Light Cycler-FastStart DNA Master SYBR Green I kit (Roche, USA). The real-time PCR reaction mixture contained $1 \mu \mathrm{l}$ of the sample and $24 \mu \mathrm{l}$ of a master mix containing $2 \mu \mathrm{l} \mathrm{MgCl}(25 \mathrm{mM}), 0.25 \mu \mathrm{FasL}$ forward and reverse primers $(10 \mu M)$ or $0.5 \mu 1 \beta$-actin primer pair $(5 \mu M), 19.5 \mu$ l water and $2 \mu \mathrm{l} \mathrm{PCR}$ core reagent ( $1 \mathrm{a}$ and $1 \mathrm{~b}$ ). Each of the 10 control and 10 experimental samples was analyzed twice with the FasL and twice with the $\beta$-actin primer sets. Each real-time PCR run consisted of 45 cycles. For FasL primers, each cycle consisted of $30 \mathrm{~s}$ of denaturation at $95^{\circ} \mathrm{C}, 40 \mathrm{~s}$ of annealing at $66^{\circ} \mathrm{C}$ and $40 \mathrm{~s}$ for enzymatic primer extension at $72^{\circ} \mathrm{C}$. For $\beta$-actin primers, each cycle consisted of $20 \mathrm{~s}$ of denaturation at $95^{\circ} \mathrm{C}, 30 \mathrm{~s}$ of annealing at $59^{\circ} \mathrm{C}$ and $30 \mathrm{~s}$ for enzymatic primer extension at $72^{\circ} \mathrm{C}$.

In each run, 6 standard samples were included in the analysis. Standard DNA was generated from the $\beta$-actin and FasL PCR-II clones, and the amount of DNA was quantified by measuring the absorbance at $280 \mathrm{~nm}$. For determining the FasL cDNA concentration in the samples, the following standard concentrations were used: $10,5,1,0.5,0.1$ and $0 \mathrm{fg} / \mu \mathrm{l}$. To measure $\beta$-actin cDNA concentration in the samples, the following standard concentrations were used: $1000,100,10,1,0.1$ and $0 \mathrm{fg} / \mu \mathrm{l}$.

For each PCR cycle, generation of the PCR product was measured by determining the fluorescence of Cybergreen, an intercalating dye that exhibits greatly increased fluorescence when bound to double-stranded DNA, in arbitrary units referenced to an internal standard. This resulted in an amplification curve that, if only a single product was amplified, exhibited a smooth S-shaped, or ogival, func- 
tion. The threshold cycle was defined by taking the second derivative of the amplification curve and determining the point of maximum change in DNA amount from the peak of the second derivative function. This method is less sensitive to background fluorescence than designating an arbitrary fluorescence level as the threshold. However, utilization of arbitrary threshold was also performed. This had no significant influence on the data nor did it change the outcome.

The PCR cycle thresholds obtained with the different concentrations of the standard were used to generate a standard curve for each PCR run. The amount of FasL and $\beta$-actin cDNA in each sample was determined by fitting the values to the respective standard curve. Some of the FasL levels detected in the samples were slightly lower than in the standards used. However, since all the standards closely followed a linear relationship, it was felt that these values were valid. Finally, the concentration of FasL cDNA was normalized using the concentration of $\beta$-actin cDNA to control for any possible differences in sample size. The relative concentration of FasL cDNA in the stimulated samples was compared to the relative concentration of cDNA in the unstimulated samples and statistically analyzed using the nonparametric Mann-Whitney U test.

\section{FasL Immunohistochemistry}

The OC was dissected and cultured as described above. Each of the tissue samples was immediately transferred into the well of a 48well tissue culture plate (Costar) in Dulbecco phosphate-buffered saline (Gibco). Four explants were pooled per well. In order to obtain a single cell suspension, explants were digested with $2 \mathrm{mg} / \mathrm{ml}$ trypsin, $2 \mathrm{mg} / \mathrm{ml}$ collagenase and $1.2 \mathrm{mg} / \mathrm{ml}$ elastase (Sigma, St. Louis, Mo., USA) for $40 \mathrm{~min}$ at $37^{\circ} \mathrm{C}$. After removal of the supernatant, $500 \mu \mathrm{l}$ PBS containing $5 \%$ fetal calf serum, Hepes buffer $0.025 \mathrm{M}$ and penicillin $30 \mathrm{U} / \mathrm{ml}$ was added per well. Cell dispersion was accomplished by trituration using a $1-\mathrm{ml}$ syringe. Each respective cell population was split into two. One aliquot was stimulated with $100 \mathrm{IU} / \mathrm{ml}$ recombinant rat IFN- $\gamma$ (R\&D Systems Inc.) for $12 \mathrm{~h}$, which was repeated $1 \mathrm{~h}$ before fixation. The other aliquot remained unstimulated.

At the end of the culturing period, the cells were fixed with $4 \%$ paraformaldehyde and permeabilized with 5\% Triton X-100 in PBS with $10 \%$ fetal bovine serum for $30 \mathrm{~min}$. The cells were washed twice with PBS and incubated for $30 \mathrm{~min}$ at $37^{\circ} \mathrm{C}$ with a polyclonal goat antimouse FasL antibody (1:100, Santa Cruz Biotechnology, USA). The cells were washed twice with PBS and incubated for $45 \mathrm{~min}$ at $4^{\circ} \mathrm{C}$ with a rabbit antigoat IgG FITC-conjugated antibody $(1: 100$, Jackson Immuno Inc., USA). Cells were again washed twice in PBS and then visualized on a confocal microscope (Carl Zeiss, Germany) with a green filter (for the FITC staining, excitation/emission wavelength $490 \mathrm{~nm} / 525 \mathrm{~nm}$ ). The primary antibody was replaced with PBS as a control for nonspecific binding.

\section{Results}

FasL mRNA Does Not Increase with IFN- $\gamma$ Treatment

We analyzed the expression of FasL along with expression of $\beta$-actin in OC maintained in culture medium or stimulated with IFN- $\gamma$, using reverse transcription and subsequent real-time PCR analysis. Analysis of the PCR products on a $1.5 \%$ agarose gel revealed the expected size

\section{a \\ $\beta$-actin}
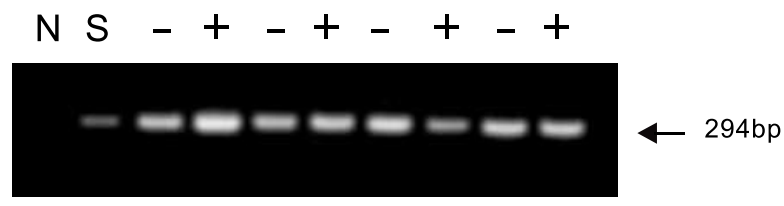

b FasL

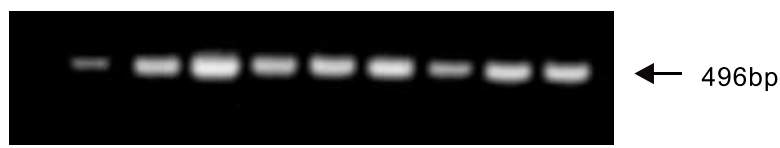

Fig. 1. Agarose gel electrophoresis of several representative OC samples after real-time PCR. A single band of the expected size is observed for $\beta$-actin (294 bp) (a) and for FasL (496 bp) (b). N = Negative control (no cDNA); $\mathrm{S}=$ standard $(0.1 \mathrm{fg} / \mu \mathrm{l}$, the lowest DNA concentration used); $-=$ unstimulated $\mathrm{OC} ;+=$ IFN- $\gamma$-stimulated OC.

of the $\beta$-actin (294 bp) and FasL (496 bp) fragments, respectively. There were no primer dimers (fig. 1), which could interfere with the determination of the concentration by real-time PCR based on Cybergreen incorporation. In addition, melting curve analysis for all real-time PCR runs demonstrated a single peak, which is consistent with the measurement of only a single, specific PCR product (data not shown). PCR of all samples generated a smooth, S-shaped growth function of fluorescence (fig. 2), also consistent with a single PCR product.

Real-time PCR of the DNA standards $(n=6)$ generated a linear relationship between PCR threshold and log concentration (fig. 2, 3). This allowed the generation of standard curves, from which the concentration of the samples could be determined. The $\beta$-actin and FasL cDNA concentrations showed only minor variation among the samples of each group. The average cDNA concentration of $\beta$-actin in the unstimulated group was 49 $( \pm 15) \mathrm{fg} / \mu \mathrm{l}$ and in the stimulated group $58( \pm 25) \mathrm{fg} / \mu \mathrm{l}$. The average cDNA concentration of FasL was 0.079 $( \pm 0.01) \mathrm{fg} / \mu \mathrm{l}$ in the unstimulated and $0.085( \pm 0.02) \mathrm{fg} / \mu \mathrm{l}$ in the stimulated group. There was no significant effect of IFN- $\gamma$ on either $\beta$-actin or FasL cDNA levels.

FasL expression levels were then normalized to $\beta$-actin expression levels to control for differences in tissue sample size again; in the IFN- $\gamma$-stimulated group $(n=10)$, the level 
$\beta$-actin standard

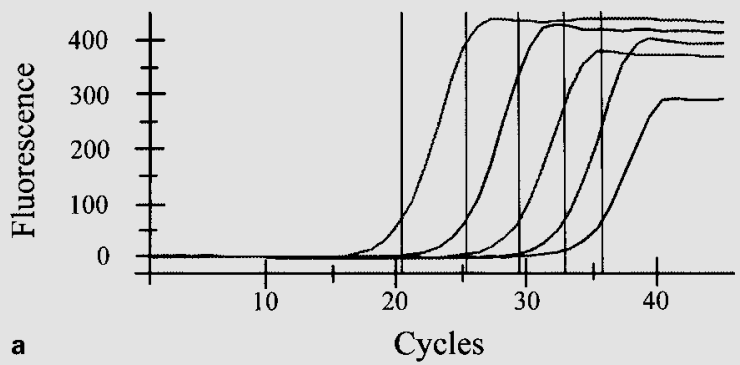

FasL standard

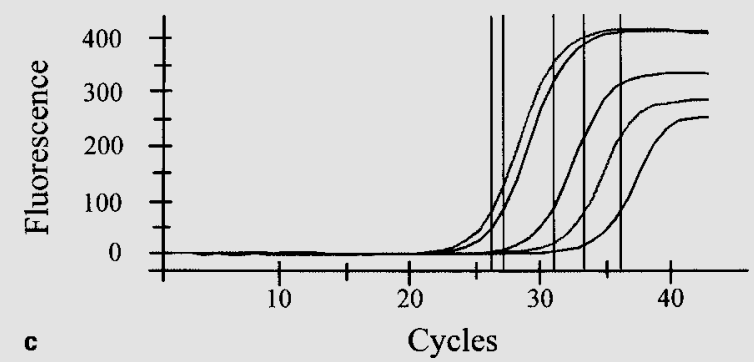

\section{$\beta$-actin OC cDNA, stimulated}

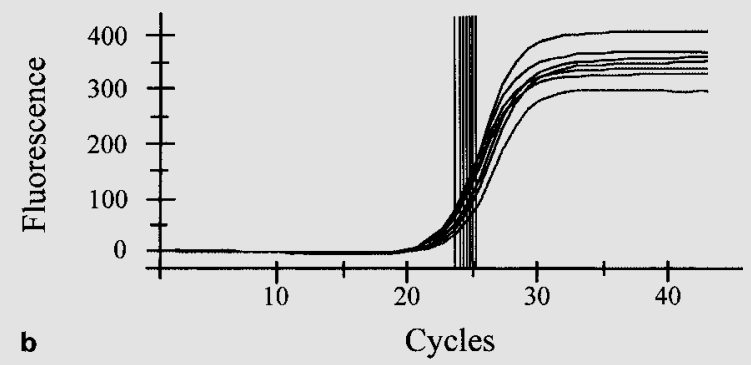

FasL OC cDNA, stimulated

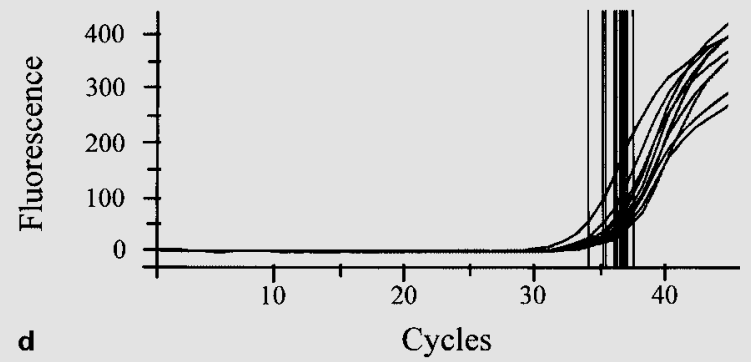

Fig. 2. Cybergreen fluorescence observed across PCR amplification cycles for representative DNA standards and IFN- $\gamma$-stimulated OC cDNA samples for $\beta$-actin $(\mathbf{a}, \mathbf{b})$ and FasL $(\mathbf{c}, \mathbf{d})$. The vertical line for each curve identifies the cycle value at which the highest rate of change of the initial rise in fluorescence, derived from the second derivative of the illustrated fluorescence function, is observed. This point which is defined as the threshold cycle, is used to compare across amplification curves. The $\beta$-actin standard concentrations (a) were 1000, 100, 10, 1, 0.1 and $0 \mathrm{fg} / \mu \mathrm{l}$. The FasL standard concentrations (c) were 10, 5, 1, 0.5, 0.1 and $0 \mathrm{fg} / \mu \mathrm{l}$. All curves are smooth, ogival functions, consistent with amplification of a single product.

of FasL was not significantly different $(\mathrm{p}=0.9)$, when compared to the unstimulated group $(n=10$, fig. 4$)$.

\section{Subcellular Localization of FasL Protein Changes with IFN- $\gamma$ Treatment}

Control OC cells showed dense intracellular concentrations of FasL immunostaining, confined to the perinuclear regions of the cells. There was no generalized staining of the cells, as would be expected with membrane localization (fig. 5a). Cells exposed to IFN- $\gamma$ for $13 \mathrm{~h}$ showed a very different pattern of immunolabeling. Perinuclear labeling was much less intense, and clumping was not observed. The label was distributed more uniformly throughout the cells, even to thin processes. It was also observed over the cell nuclei, and in some cases a uniform label obscured the cell nucleus (fig. 5b).

\section{Discussion}

In the present study, we found extremely low levels of FasL transcripts in cDNAs from OC cells, compared to $\beta$-actin sequences. This suggests that the level of transcription of the FasL gene is also low, or that the FasL message is unstable, either of which possibility would lead to low levels of protein translation. Moreover, there was no increase in FasL transcripts and/or mRNA stability in the OC after IFN- $\gamma$ stimulation. This result suggests that the increases in FasL that we previously observed on cochlear cells exposed to inflammatory stimulation [Bodmer et al., 2002] are not related to changes in gene transcription. It further suggests the possible presence of preformed FasL in normal cochlear cells, protein that is sequestered from FACS and standard cytochemical analysis. 


\section{$\beta$-actin, unstimulated OC cDNA}

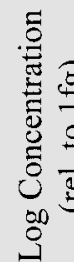

a

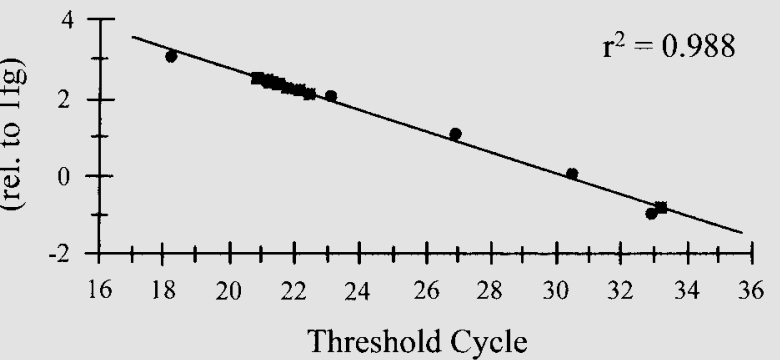

FasL, unstimulated OC cDNA

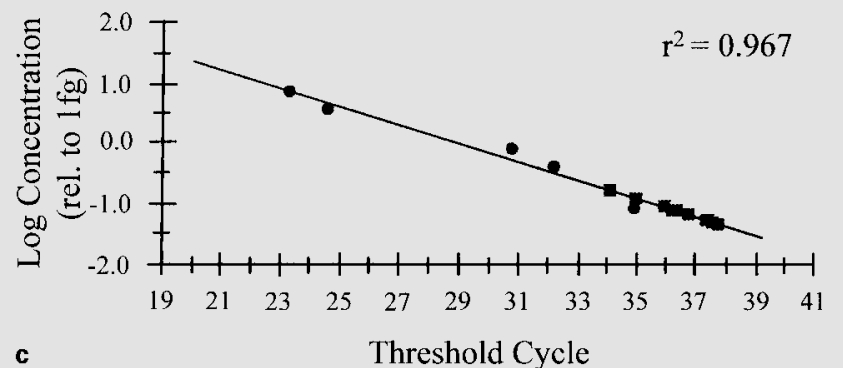

C $\beta$-actin, stimulated OC cDNA

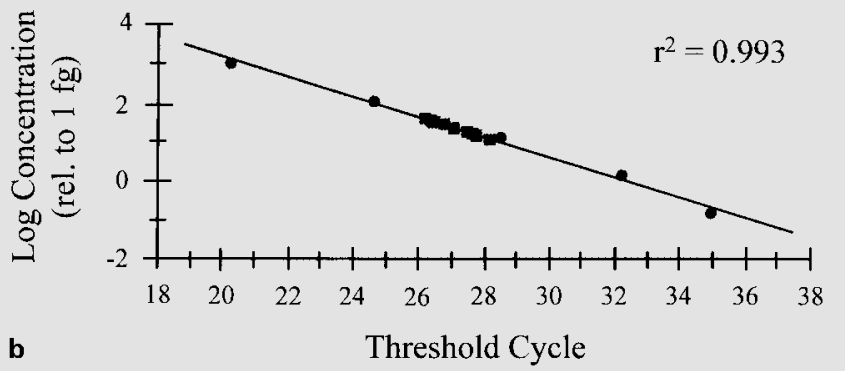

FasL, stimulated OC cDNA

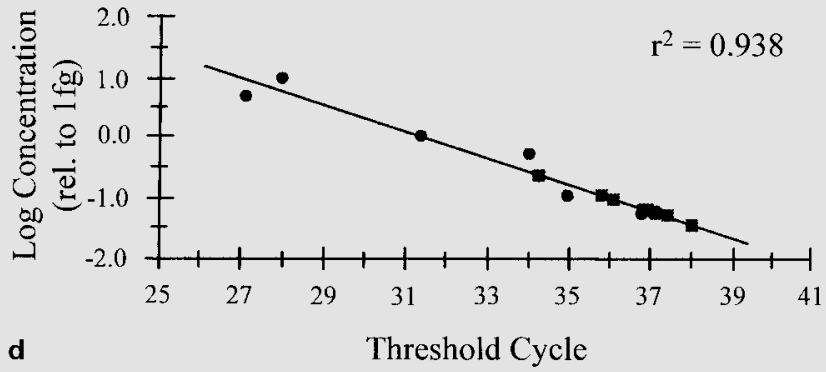

OC sample

Fig. 3. cDNA concentrations, derived from standard and OC sample amplification curves, plotted against threshold cycle, for $\beta$-actin $(\mathbf{a}, \mathbf{b})$ and FasL $(\mathbf{c}, \mathbf{d})$. Standard thresholds represented by circles were used to generate the best fit function. The points fall close to the best-fit straight lines throughout the cycle range, as indicated by the correlation coefficient of each plot. The sample values are represented by squares and were fit to the straight lines to determine their value. The points represented in $\mathbf{b}$ and $\mathbf{d}$ were generated from the cycle threshold data in figure 2 .

Fig. 4. Relative expression of FasL, corrected by $\beta$-actin expression, in the unstimulated and IFN- $\gamma$-stimulated OC. Bars indicate standard errors of the mean. Analysis by Mann-Whitney U test indicated no significant difference in cDNA ratio between the two conditions $(p=0.9)$.

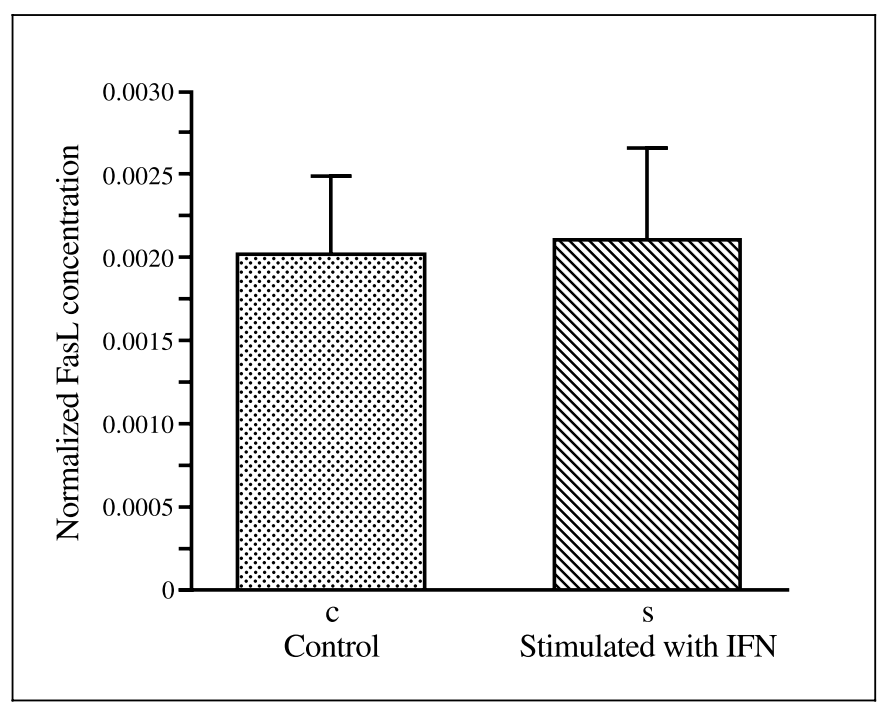

Audiol Neurootol 2003;8:243-249 

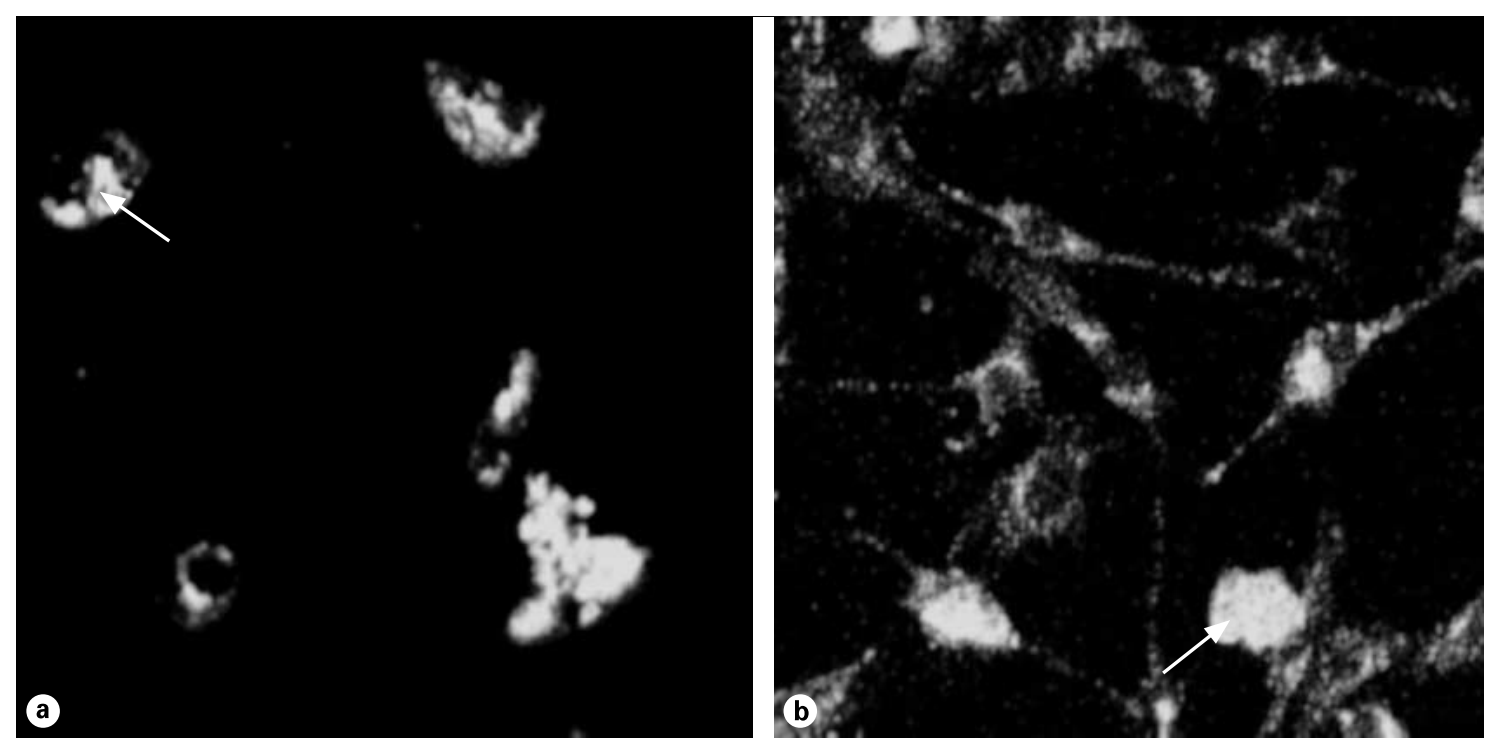

Fig. 5. Confocal immunocytochemistry illustrating subcellular localization of FasL protein in dissociated cells from the OC. a Unstimulated OC cells. These cells showed intracellular concentrations of FasL immunostaining, especially in the perinuclear region of the cell (arrow), but no generalized staining of the cell or cell membrane. b OC cells stimulated with IFN- $\gamma$ for $13 \mathrm{~h}$. These cells showed less staining of the perinuclear region and strong staining throughout the cell (arrow).

To assess this possibility, we evaluated the cellular distribution of FasL, in cells that were dispersed and extensively permeabilized to expose intracellular proteins, by confocal microscopy. Using this method, we found intense, clumped FasL immunoreactivity in the perinuclear region of unstimulated OC cells. This is consistent with FasL being tightly sequestered in intracellular compartments such as the endoplasmic reticulum, Golgi apparatus or storage vesicles. After IFN- $\gamma$ stimulation, immunoreactivity in the perinuclear regions was reduced, and labeling was widely distributed, in OC cells. The pattern of labeling was consistent with cytoplasmic and/or membrane distribution of FasL.

This finding is in agreement with results obtained from studies on cytotoxic T lymphocytes, where it has been demonstrated that expression of FasL on the cell surface of activated lymphocytes was blocked by brefeldin A, an inhibitor of intracellular protein transport, but not by protein synthesis inhibition [Li et al., 1998]. In addition, avoiding biosynthesis and having enough protein stored makes it possible for a cell to respond very quickly to extracellular stimuli.

It should be noted that OC cells were exposed to IFN- $\gamma$ for a total of $13 \mathrm{~h}$ and that the last addition of IFN- $\gamma$ was $1 \mathrm{~h}$ before mRNA isolation. Therefore, it is possible that FasL transcription occurred prior to or after the period tested. However, we showed in a time course study using FACS analysis that IFN- $\gamma$-stimulated FasL appeared on the cell surface after $6 \mathrm{~h}$ of stimulation, with maximal surface expression observed after $48 \mathrm{~h}$ of stimulation [Bodmer et al., 2002]. In this prior study, we stimulated the OC every $12 \mathrm{~h}$ with IFN- $\gamma$. This makes it likely that we would have seen an increase in gene expression after $13 \mathrm{~h}$, if the FasL increase seen by FACS was due to upregulated gene transcription. We noted levels of variability in $\beta$-actin cDNAs that were about twice as great as those measured for FasL. This may represent a technical difficulty. However, it is also possible that the FasL message is more tightly regulated in OC cells.

In our previous study [Bodmer et al., 2002], FasL was observed on supporting cells in the $\mathrm{OC}$ of sections from animals undergoing a cochlear secondary immune response. No labeling was observed in hair cells. In the present study, we did not identify the OC cells labeled with anti-FasL antibody. However, the OC consists of hair cells and supporting cells. The fact that virtually all cells showed changes in FasL distribution, and that hair cells survive poorly in dispersed tissue culture, suggests that the changes observed in the present study occurred in supporting cells.

The function of FasL translocation to OC cell membranes is not clear. It is possible that FasL serves to pro- 
tect the hair cells of the $\mathrm{OC}$ from immune and inflammatory cells bearing Fas on their surfaces. A similar function for FasL has been proposed to occur in the anterior chamber of the eye [Griffith et al., 1996]. In the OC, expression of FasL on supporting cells could serve to protect the hair cells, which are surrounded by supporting cells. Relevant to this hypothesis, mice deficient in Fas have been proposed to be a model for autoimmune inner ear damage [Trune et al., 1989]. Alternatively, FasL could participate in the death of OC cells in response to stress. Additional studies on the effects of FasL in the inner ear would be required to address this issue.

Although real-time PCR is a very sensitive technique, the method used to isolate sufficient mRNA from cochlear tissue is critical for successful downstream applications. We found that isolation of mRNA from cochlear tissue with magnetic microbeads provides enough starting material for successful reverse transcription and subsequent real-time PCR analysis. However, it is essential that mRNA be released from the beads prior to the reverse transcription and real-time PCR analysis, as we found that the beads interfere with the optical detection system of real-time PCR. The levels of mRNA present in our original samples cannot be determined, since the efficien- cies of mRNA extraction and reverse transcription are not known. However, it seems reasonable to assume the efficiencies were similar in the two experimental conditions. It should be noted that one value obtained for $\beta$-actin in a control OC was very low (fig. 3a). There was no reason to exclude these data, and so they were left in the study. However, analysis without this sample yielded the same results.

Real-time PCR has been used to assess gene expression in cells of vestibular origin [Uno et al., 2000, 2002]; however, to our knowledge this is the first report of the application of real-time PCR analysis to cells of the cochlea. The present study demonstrates that it is possible to obtain sufficient mRNA for real-time PCR from cochlear tissue, and it confirms the utility of the technique for cochlear cells.

\section{Acknowledgements}

This work was supported by funds from the Schweizerischer Nationalfonds, the Deutsche Forschungsgemeinschaft (grant BR 2141/1-1), the NIH/NIDCD (grant DC00139) and the Research Service of the Veterans Administration.

\section{References}

Bellgrau D, Gold D, Selawry H, Moore J, Franzusoff A, Duke RC: A role for CD95 ligand in preventing graft rejection. Nature 1995;377:630 632 .

Bodmer D, Brors D, Pak K, Keithley EM, Mullen L, Ryan AF, Gloddek B: Inflammatory signals increase Fas ligand expression by inner ear cells. J Neuroimmunol 2002;129:10-17.

Griffith TS, Yu X, Herndon JM, Green DR, Ferguson TA: CD95-induced apoptosis of lymphocytes in an immune privileged site induces immunological tolerance. Immunity 1996;5:716.

Housley GD, Greenwood D, Bennett T, Ryan AF: Identification of a short form of the P2xR1purinoceptor subunit produced by alternative splicing in the pituitary and cochlea. Biochem Biophys Res Commun 1995;212:501-508.

Kluck RM, Bossy-Wetzel E, Green DR, Newmeyer DD: The release of cytochrome c from mitochondria: A primary site for Bcl-2 regulation of apoptosis. Science 1997;275:1132-1136.
Li JH, Rosen D, Ronen D, Behrens CK, Krammer PH, Clark WR, Berke G: The regulation of CD95 ligand expression and function in CTL. $\mathrm{J}$ Immunol 1998;161:3943-3949.

Nagata S, Golstein P: The Fas death factor. Science 1995;267:1449-1456.

Oshimi Y, Oda S, Honda Y, Nagata S, Miyazaki S: Involvement of Fas ligand and Fas-mediated pathway in the cytotoxicity of human natural killer cells. J Immunol 1996;157:2909-2915.

Sobkowicz HM, Loftus JM, Slapnick SM: Tissue culture of the organ of Corti. Acta Otolaryngol Suppl 1993;502:3-36.

Suda T, Okazaki T, Naito Y, Yokota T, Arai N, Ozaki S, Nakao K, Nagata S: Expression of the Fas ligand in cells of T cell lineage. J Immunol 1995; 154:3806-3813.

Suda T, Takahashi T, Golstein P, Nagata S: Molecular cloning and expression of the Fas ligand, a novel member of the tumor necrosis factor family. Cell 1993;75:1169-1178.

Trune DR, Craven JP, Morton JI, Mitchell C: Autoimmune disease and cochlear pathology in the C3H/lpr strain mouse. Hear Res 1989;38: $57-66$.
Uno Y, Horii A, Umemoto M, Hasegawa T, Doi K, Uno A, Takemura T, Kubo T: Effects of hypergravity on morphology and osteopontin expression in the rat otolith organs. J Vestib Res 2000;10:283-289.

Uno Y, Horii A, Uno A, Fuse Y, Fukushima M, Doi K, Kubo T: Quantitative changes in mRNA expression of glutamate receptors in the rat peripheral and central vestibular systems following hypergravity. J Neurochem 2002;81:1308-1317.

Van de Water T, Ruben RJ: Symposium: New data for noise standards. 3. Organ culture of the mammalian inner ear: A tool to study inner ear deafness. Laryngoscope 1974;84:738-749.

Van de Water TR, Ruben RJ: Organ culture of the mammalian inner ear. Acta Otolaryngol 1971; 71:303-312.

Zimmermann KC, Bonzon C, Green DR: The machinery of programmed cell death. Pharmacol Ther 2001;92:57-70. 